\title{
IAMJ
}

INTERNATIONAL

AYURVEDIC

MEDICAL JOURNAL

Research Article

ISSN: 2320-5091

Impact Factor: 6.719

\section{EFFECT OF CITRAKADI KSARA LĒPA IN THE MANAGEMENT OF SECOND-DEGREE INTERNAL HAEMORRHOIDS}

\author{
Basima A.P. ${ }^{1}$, Rejani H. ${ }^{2}$ \\ ${ }^{1}$ PG Scholar, ${ }^{2}$ Professor, \\ Department of Shalyatantra, VPSV Ayurveda College, Kottakkal, Kerala, India
}

Corresponding Author: basimaedavanna@gmail.com

\section{https://doi.org/10.46607/iamj0709102021}

(Published Online: October 2021)

Open Access

(C) International Ayurvedic Medical Journal, India 2021

Article Received: 27/09//2021 - Peer Reviewed: 06/10/2021 - Accepted for Publication: 08/10/2021

\section{Check for updates}

\begin{abstract}
Background and Objectives: Haemorrhoids are dilated veins within the anal canal in the sub-epithelial region formed by radicles of superior, middle, and inferior rectal veins. It hampers the routine life of an affected person. In India about $50 \%$ of the population would have haemorrhoids at some point in their life. Achärya Vāgbhata defines Arsas (haemorrhoids) as an abnormal growth which obstructs the anal canal and troubles continuously like an enemy The objective of the study is to assess the efficacy of citrakādi kșāra lēpa in the management of seconddegree internal haemorrhoids. The study also aims to find out an easy, effective and less complicated procedure for second-degree haemorrhoids. The 15 participants with second degree internal haemorrhoids were selected as per inclusion criteria. After doing all the preoperative procedures, the citrakādi kșāra lēpa was done in a single sitting. The duration of the study was 30 days. The assessment of reduction of size of haemorrhoids, mucosal changes after the procedure and frequency of bleeding were done before the treatment, on $1^{\text {st }}, 3^{\text {rd }}, 5^{\text {th }}, 7^{\text {th }}, 15^{\text {th }}$, and $30^{\text {th }}$ day using the required assessment tools. The symptoms, constipation and mucous discharge were assessed on the $0^{\text {th }}$ and $30^{\text {th }}$ days. The follow up was done on the $60^{\text {th }}$ day. The statistical analysis of the results was done using nonparametric tests. On analysing, it was found that the Citrakādi kșāra shows $86.11 \%$ of the efficacy in the reduction of both subjective and objective parameters.
\end{abstract}

Key words: Haemorrhoids, Arsas, Citrakādi kșāra 


\section{INTRODUCTION}

Haemorrhoids are dilated veins within the anal canal in the sub-epithelial region formed by radicles of superior, middle and inferior rectal veins ${ }^{1}$. Today haemorrhoids remain the most common anorectal disease. ${ }^{2}$ The Current theory says that haemorrhoids are formed by the sliding down of the anal cushion, which consists of aggregation blood vessels (arterioles, venules and arterio venule communication), smooth muscles, and elastic connective tissue in the mucosa ${ }^{3}$. The term haemorrhoids have been derived from the Greek word, haema- means blood, and rhoos- means flowing. The literary meaning of haemorrhoids is 'blood to ooze ${ }^{4}$. The overall prevalence of haemorrhoid was high, and its prevalence was higher in male subjects. The estimated worldwide prevalence of haemorrhoids in the general population is to be $4.4 \%^{5}$. The exact causes of haemorrhoids are unknown. Several contributory anatomical factors have been implicated, including the upright posture of humans, ageing, pregnancy, heredity, chronic constipation, chronic diarrhoea, obesity, derangement of the internal anal sphincter, straining for defecation, spending excessive periods of time on the toilet, abdominal tumours, cancer of the rectum, sedentary habit ${ }^{6-8}$. Haemorrhoids are classified based on their site of origin, pathological anatomy and clinical stages.

According to the site of origin, haemorrhoids are three types $^{9}$

1. Internal haemorrhoid-it is within the anal canal and above the dentate line. It is covered with a mucous membrane.

2. External haemorrhoid - it is situated outside the anal canal and below the dentate line. It is covered by skin.

3. Intero external haemorrhoids - both the above varieties coexist.

According to pathological anatomy, haemorrhoids are of two types.

1. Primary haemorrhoids - located at $3,7,11$ o'clock positions related to the superior haemorrhoidal vessel.
2. Secondary haemorrhoids - haemorrhoids may be secondary to a few conditions like rectal cancer, pregnancy, chronic constipation, difficulty in micturition, portal hypertension.

According to clinical stages, these are four in number.

1. First-degree haemorrhoids - they do not come out of the anus during defecation.

2. Second-degree haemorrhoids - they come out only during defecation and return by

themselves.

3. Third-degree haemorrhoids - they come out during defecation and do not return by themselves and require manual reduction.

4. Fourth-degree haemorrhoids - these are permanently prolapsed.

In modern medicines, there are many operative and non-operative procedures for the management of haemorrhoids such as sclerotherapy, rubber band ligation, cryosurgery, haemorrhoidectomy, harmonic ultrasonic scalpel haemorrhoidectomy, doppler guided haemorrhoidal artery ligation ${ }^{10}$. Many of them are not patient-friendly, causing a high economic burden, and associated with complications like pain, bleeding and recurrence of haemorrhoids. Acārya Suśruta mentions four therapeutic measures for the management of arsas (haemorrhoid). They are bhēṣaja, kșāra karma, agni karma and śastra karma. Among these procedures. Kșāra karma is the choice when the haemorrhoids are mridu (soft), prasruta(spread), avagā is an alkaline substance obtained from the ashes of medicinal herbs. It works as a chemical cauterizing agent. Kșâra is two types based on the application, they are pānīya kșāra (internal) and prathisāranīya Kșāra (external). Other classifications of kșāra are mrdhu, madhyama and teekshna on the basis of potency. Ksara is considered best among sastra (surgical) and anusastra (para surgical). It works as chèdana, bhèdana, lēkhana and alleviates three doșas. ${ }^{12}$ Susruta samhita explains a detailed description of the preparation of Kșāra. Here, a modified form of 
citrakādi prathisārana Kșāra was prepared by changing the quantity of each ingredient in order to increase the potency of particular kșâra.

METHODOLOGY: The study setting was OPD and IPD of VPSV Ayurveda College Kottakkal. Participants satisfying the diagnostic and inclusion criteria were randomly selected using the random number table method.

\section{DIAGNOSTIC CRITERIA}

\section{- Clinical symptoms}

Mass protruding per rectum during defecation and return by itself, Mucous discharge, Constipation

- On examination

Inspection

Proctoscopy examination

\section{INCLUSION CRITERIA}

- Participants with Second-degree internal haemorrhoids

- Participants with age 21-60yrs

- Arśas with mridu (soft), prasruta (spread), avagạ̈̂ha (deep) and ucchrita (projected)

- Participants with the informed written consent

\section{EXCLUSION CRITERIA}

- Participants with Irritable Bowel Syndrome, Tuberculosis, Intra-abdominal pathology, Diabetes mellitus, HIV and Crohn's disease.

- The participant is under anticoagulants

- Haemorrhoids with complications

- Haemorrhoids developed as secondary to neoplasm, inflammatory bowel disease, fistula, rectal prolapse, abscess and fissure.

- Kẽvala Paitika arśas

\section{INTERVENTION}

Citrakādi kșāra lepa in second-degree internal haemorrhoids

\section{A. Method of preparation of Citrakādi $k \underline{s} \bar{a} r a^{13}$}

2.5 Kilograms of chiruvilwa, naktamāla, sodida citraka and apamārga will be collected and dried in sunlight. Then it will be made into small pieces. The collected drugs and chürnaka (limestone) will be made into ash by burning and collected separately. Obtained plant ash should be mixed with 6 times of pure water and stirred. Then the solution will be filtered through a two-layer clean cloth piece 21 times. The filtrate will be separated. Then the solution will be poured into an iron vessel and heated. The total height of a column of the solution will be calculated to know the reduction of the solution. The collected Varațika made it into red hot with the help of crucible and coal fire. The red hot Varātika is taken out and made into powder form and then mixed with the bhasma of limestone. When the solution will be reached to red colour and slimy, 200 $\mathrm{ml}$ of liquid will be collected and half of it stored as kșāra Jala and the remaining solution will be mixed with varātika powder and then poured into boiling solution. $10 \mathrm{gm}$ of śodida prakșēpa chūrna kalkās (danti, ativișa, hingu, vaca) will be made into paste form and added to solution when will be stirred slowly up to semisolid form got. The prepared kșāra will be collected and stored in an airtight glass container.

\section{B. Method of application}

Preoperative Procedure: Prior to the procedure, the participant was advised to take a light diet. The perianal area was prepared well, and an enema was given in the early morning.

Operative Procedure: The participants were made to lie in the lithotomy positions. The anal and perianal areas were cleaned with an antiseptic solution. Then the proctoscope smeared with anaesthetic jelly was introduced into the anal canal to detect the exact position of pile mass. Then the pile mass was cleaned with a cotton swab and the surrounding area was covered with cotton to avoid injury. Then $3 \mathrm{gm}$ citrakādi kșāra was applied over the pile mass with the help of śalāka and retained for 30 minutes or till the pile mass turned to purple-black colour (pakva jambu phala varna). After this procedure, the anal canal was washed with sterile tamarind water and wiped. This helps to neutralize $\mathrm{P}^{\mathrm{H}}$ and to remove all the remaining kșāra. Then, ghee prepared with yaști Madhu was smeared over the area and the proctoscope was removed ${ }^{14}$.

Post-operative: Sitz bath with lukewarm water for two weeks

Gandhaka rasāyana tablet for 1week (2-0-2)

Triphalachūrna+guggulu paňcha pala chūrna $5 \mathrm{gm}$ with hot water two times daily for 2 weeks 
The clinical assessments, reduction of the size of haemorrhoidal mass, frequency of bleeding and mucosal changes was done before the treatment, on $1^{\text {st }}$, $3^{\text {rd }}, 5^{\text {th }}, 7^{\text {th }}, 15^{\text {th }}$, and $30^{\text {th }}$ day using the required assessment tools. The symptoms, constipation and mucous discharge were assessed on the $0^{\text {th }}$ and $30^{\text {th }}$ days. The follow up was done on the $60^{\text {th }}$ day. The statistical analysis of the results was done using nonparametric tests.

Table 1: Data obtained after statistical analysis

\begin{tabular}{|l|l|l|l|l|l|l|}
\hline Variables & \multicolumn{2}{|l|}{ Reduction of the size of haemorrhoids } & \multicolumn{2}{l|}{ Frequency of bleeding after the procedure } & \multicolumn{2}{l|}{ Mucosal changes } \\
\hline & Mean \pm SD & P value & Mean \pm SD & P value & Mean \pm SD & P value \\
\hline D0 & $3.0 \pm .00$ & $<0.001$ & & & $6.3 \pm .72$ & $<0.001$ \\
\hline D1 & $1.2 \pm .41$ & $<0.001$ & $0.40 . \pm .91$ & $<0.05$ & $1.8 \pm 1.6$ & $<0.001$ \\
\hline D3 & $1.1 \pm .35$ & $<0.001$ & $0.40 . \pm .73$ & $<0.05$ & $2.4 \pm .83$ & $<0.001$ \\
\hline D5 & $0.73 \pm .70$ & $<0.001$ & $0.20 . \pm .56$ & $<0.05$ & $3.2 \pm .88$ & $<0.001$ \\
\hline D7 & $0.53 \pm .83$ & $<0.001$ & $0.13 . \pm .35$ & $<0.05$ & $4.5 \pm 1.06$ & $<0.001$ \\
\hline D15 & $0.46 \pm .99$ & $<0.001$ & $0.06 . \pm .25$ & $<0.05$ & $5.6 \pm .97$ & $<0.001$ \\
\hline D30 & $0.40 \pm .91$ & $<0.001$ & $0.06 . \pm .25$ & $<0.05$ & $6.5 \pm .63$ & $<0.001$ \\
\hline D60 & $0.40 \pm .91$ & $<0.001$ & $0.13 . \pm .51$ & $<0.05$ & $6.5 \pm .63$ & $<0.001$ \\
\hline
\end{tabular}

Table 2: Data obtained after statistical analysis

\begin{tabular}{|l|l|l|l|}
\hline Variables & Before treatment & After treatment & \\
\hline & Mean \pm SD & Mean \pm SD & P value \\
\hline Constipation & $0.60 \pm .50$ & $0.13 \pm .35$ & $<0.05$ \\
\hline Mucous discharge & $0.33 \pm .48$ & $0.00 \pm .00$ & $<0.05$ \\
\hline
\end{tabular}

Figure 1: Effect of Citrakādi kșāra lepa in the management of second-degree internal haemorrhoids

\section{Total efficacy}

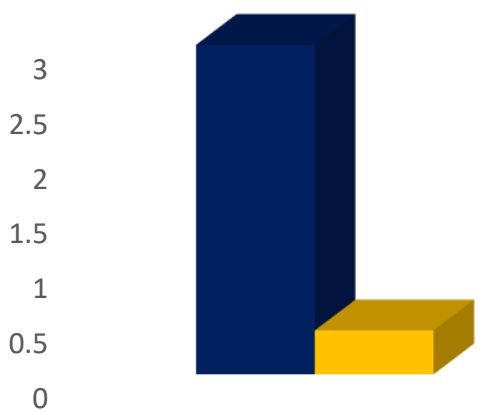

Size of haemorrhoids

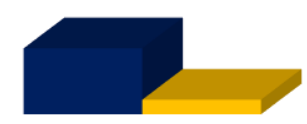

Constipation

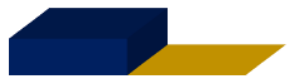

Mucous discharge

Before treatment $\square$ After treatment

\section{DISCUSSION}

Meaningful discussions and thoughtful explorations are always a necessity for the development and sustainment of any branch of medicine in the current competitive world, Ayurvēda being no exception. The eternity of Ayurvēda should be preserved by new research works and good scientific discussions. Today haemorrhoids remain the most common anorectal disease, which hampers the routine life of an affected person. In modern science, there are many surgical and 
non-surgical procedures for the management of haemorrhoids, but most of them are costly. Often many patients are unfit for such surgical procedures. Haemorrhoid is one of the most common diseases of the anal canal. The anal canal consists of three fibrovascular cushions that are fed directly by arteriovenous communications. These cushions are supported within the anal canal by a connective tissue framework, and they are important in providing a watertight seal to the anus. The degenerative effects of ageing, strenuous work and repeated passage of hard stool may weaken or fragment the supporting tissues and produces a shearing force on the cushions, leading to their descent and prolapse. The prolapsed cushions have impaired venous return, which results in engorgement of veins that may be further exacerbated by straining, inadequate fibre intake, prolonged time on the lavatory, and conditions such as pregnancy that raise intra-abdominal pressure. Bleeding from the engorged prolapsed haemorrhoid occurs as a result of localised mucosal trauma or inflammation, which damages the underlying haemorrhoidal veins ${ }^{15}$. The exact incidence of this common condition is difficult to estimate as many people are reluctant to seek medical advice due to various personal, cultural, and socioeconomic reasons.

$\bar{A} c \bar{a} r y a$ Caraka described haemorrhoids are formed mainly due to two reasons ${ }^{16}$. They are dietary factors and factors related to lifestyle. The dietary factors include the usage of dietary ingredients that leads to the vitiation of Agni. The lifestyle factors especially sedentary habits and travelling leading to vitiation of dosha, especially apāna vāyu which is normally responsible for physiological functions of the anorectal region. These two factors have a major role in the manifestation of arsias. Genetic factors have also been considered in the aetiology of sahaja arisas. Susruta explained vitiation of dōṣa is mainly due to excessive and incompatible food, some postures like sitting on haunches, excessive riding which creates pressure on the anal region, sexual indulgence, suppression of normal urge of micturition and defaecation. That led to agni mandya finally arsias will develop ${ }^{17}$.
Acārya Suśruta mentions four therapeutic measures for the management of arśas (haemorrhoid). They are bhēșaja, kșāra karma, Agni karma and śastra karma. Kșāra can be used in two ways; internally as pāniya kșāra and externally as prathisāranīya Kșāra. Application of Prathisāranīya kșāra will cause complete excision of arsias with mridu(soft), prasruta(spread), avagāạha(deep) and ucchrita(projected). Hence it was decided to conduct a study on the effect of citrakādi kșära leppa in the management of second-degree haemorrhoids.

In this study, the age group of patients was selected between 20-60 years. In the present study, 36.66\% of the patients were in the age group of 31-40 years, similarly another $36.66 \%$ was in between $51-60$ years and $20 \%$ was in between $41-50$ years age limits. This data indicates that the disease is more common in the $3^{\text {rd }}$ and $6^{\text {th }}$ decades of life. The increase in the incidence in middle age may be due to their lifestyle changes and most of the following unhealthy diet. Increased incidence above middle age may be due to the increased laxity of the muscles of the perineum which causes the anal cushions to descend. Haemorrhoids are commonly seen in old age ${ }^{18}$ but nowadays which is equally distributed in middle age also because of their unhealthy lifestyle and diet. Out of 30 participants, $57 \%$ were male and $43 \%$ were female. This data justifies the male predominance in the incidence of haemorrhoids. Generally, in an Anorectal Clinic, the number of female patients is less compared to males ${ }^{19}$. The lower incidence of females in the study may be due to the less willing to consult a doctor for anorectal diseases. Most of them have difficulty exposing their private parts. In this study, $67 \%$ of participants had a constipated bowel. Constipation depends upon dietetic habits, lifestyle and also due to muscle laxity of the anal canal. It is also an indicator of apāna vāyu vaigunyam which is a root cause of arsias also. Apāna vāta in guda regulates the normal physiology of the rectum and causes timely excretion of faeces. This not only keeps the large intestine clean and healthy but also reduces pressure over the gudavali ${ }^{20}$. Therefore constipation due to derangement apāna vāta exert more pressure on that 
region resulting in dilatation of haemorrhoidal veins and sliding down of supporting muscles. In the present study, $33 \%$ of participants had a mucous discharge. In haemorrhoids, mucous discharge is found commonly in the third and fourth degree due to continuous irritation of the mucosa. But second-degree haemorrhoids were selected for this study. It may be the reason for mucous discharge was noticed in only $33 \%$ of patients due to the increased size of the mass. The influence of unhealthy dietary habits and lifestyles on the formation of haemorrhoids has been widely recognized in the literature. Prolonged Unhealthy dietary habits lead to agnimāndya which may result in the manifestation of arisas. In the present study, 26.6\% of participants were non-vegetarians and mixed diet. Non-vegetarian food is low in its fibre content and causes difficulty in digestion ${ }^{21} .36 .6 \%$ of participants had a history of chronic constipation and nonvegetarian food consumption. Which causes vitiation of Agni. 20\% of participants had a history of constipation only. $6.6 \%$ of participants had a history of non-vegetarian food consumption and job with long travelling. Long term travel also causes increased pressure on the perianal region, resulting in the sliding down of the anal cushion. These reports reflect that unhealthy food habits and lifestyles are important risk factors for the formation of haemorrhoids. $43.4 \%$ of participants had travelling habits, especially motorcycles. It causes increased pressure on the buttock region resulting in the sliding down of the anal cushion. The influence of riding on horses, elephants, camels and sitting on uneven surfaces is has been widely recognized in the literature as predisposing factors for the development of arsias. In the present study, the mean weight of the participants was $68.6 \mathrm{~kg}$. This reflects that obesity is an important factor in the development of haemorrhoids. Obesity causes fat deposition and muscle laxity of the smooth muscles that support and hold haemorrhoidal veins resulting in the sliding down of haemorrhoids ${ }^{22}$.

Table 3: Probable mode of action of pratisāranīya kșāra in ars்as

\begin{tabular}{|l|l|}
\hline Property of Kșāra \\
\hline Tīkșna \\
\hline Pācana \\
\hline Vilayana \\
\hline Śōana \\
\hline Stambana \\
\hline Lēkhana
\end{tabular}

Action on haemorrhoids

Penetrating action

Aseptic inflammation

Liquefaction of dosha

Cleanses the area, antimicrobial action

Arresting of discharge

Scraping out debridement and unhealthy tissue
Pratisāranīya kṣāra acts on haemorrhoids in four ways.

1. It cauterizes the pile mass because of its kșaranaguna (Corrosive nature).

2. It coagulates the tissue protein in the haemorrhoids that directly causes necrosis of local pile mass.

3. It eases the sloughing of the necrosed pile mass due to its sōdana property.

4. Prevention of recurrence.

The mode of action starts immediately after application on the tissue. The coagulation of protein leads to the disintegration of haemoglobin into haem and globin. Further, necrosis of the tissue in the haemorrhoidal vein will occur. The synergy of these actions results in decreasing the size of the pile mass. This necrosed tissue slough out as brown discharge, the tissue becomes fibrosed and a scar is formed Adhesion of mucosal, submucosal coat helps in prevention of further dilatation of veins and prevents prolapse of regional mucosa of the anus. This makes permanent radical obliteration of Hemorrhoids. During the oozing of blood, which is ceased by cauterization property of kșāra and coagulation of protein will occur. Hence there was no chance of bleeding during the kșâra application. The chance of infection is very least due to the sustained antimicrobial action of Kșāra ${ }^{23}$. The participants 
selected for the study had a 2nd-degree pile mass. On analysing the symptom, size of haemorrhoid in the trial group, the mean rank reduced from 7.90 to 3.03 throughout the treatment period ie, D0, D1, D3, D5, D7, D15, D30, which is highly significant with $\mathrm{p}<0.001$. In the study, $60 \%$ of patients had constipation before treatment. But after the kșāra application, it became $13 \%$. On analysing constipation mean value of D0 was reduced from .6000 to .1333 in AT. The majority of the patients had a feeling of incomplete evacuation and fullness of the rectum even after defaecation. This may be due to prolapsed pile mass. This was effectively reduced after the application of citrakādi Kșāra. It can be explained as the mass inside the anorectal region is reduced significantly after the therapeutic burn produced by Citrakādi Kșāra lēpa. The obstruction while passing the stool is removed and the anuloma Gati of apāna vāyu took place. In the present study, $33.33 \%$ of patients had mucous discharge before the treatment. But after the kṣāra application, it became $0 \%$. On analysing the mucous discharge, the mean value of D0 reduced from .3333 to .0000 in AT. The mucous discharge (Slaișmika Srāva) is the typical lakșana of Kapha vitiation. Since the kșāra got tridoshagna property, it can also alleviate Kapha and Slaișika Srāva. Due to stambana property of Kșāra. The present study shows that if the size of the haemorrhoid is large, the number of haemorrhoids are more than the kșāra is most applicable. The present study shows that if the prakrti of a patient is pitta, kșāra application produces severe burning sensation and fever.

\section{CONCLUSION}

Citrakādi Kṣāra lēpa shows $86.11 \%$ of overall efficacy in reducing the size of haemorrhoids, constipation and mucous discharge.

\section{REFERENCES}

1. Rajasree G. Anorectal Disorders Ayurvedic Approach. Varanasi: Chaukambha Orientalia; 2015; P.16-71

2. Agarwal N, Singh K, Sheikh P, Mittal K, Mathai V, Kumar A. Executive Summary - The Association of Colon \& Rectal Surgeons of India (ACRSI) Practice
Guidelines for the Management of Haemorrhoids2016. Indian J Surg. 2017; 79 (1):58-61. Doi: 10.1007/s12262-016-1578-7

3. Norman S. Williams, Christepher J.K. bulstrode, P Ronan 'o Connel (ed.) Short practice of surgery. $25^{\text {th }}$ edition. Great Britain: Edward Arnold Ltd;2008.p. 1253.

4. Villalba H, Abbas MA. Haemorrhoids: Modern Remedies for an Ancient Disease. The Permanente Journal. 2007; 11 (2):74.

5. Sss

6. Burkitt DP, Graham-Stewart CW. Haemorrhoidspostulated pathogenesis and proposed prevention. Postgraduate medical journal. 1975 Sep 1; 51 (599):631-6.

7. Loder PB, Kamm MA, Nicholls RJ, Phillips RK. Haemorrhoids: pathology, pathophysiology and aetiology. British Journal of Surgery. 1994 Jul; 81 (7):946-54.

8. S. Das. A Concise Textbook Of Surgery With Orthopaedics and Fractures. $4^{\text {th }}$ edition. Culcutta. Dr. S. Das; 2006.p.1078.

9. Agbo SP. Surgical management of haemorrhoids. Journal of surgical technique and case report. $2011 \mathrm{Jul}$; $3(2): 68$

10. Saxena P, Bhakuni YS. A prospective study on suture ligation of internal haemorrhoids without Doppler guidance for the treatment of symptomatic haemorrhoid disease. International Surgery Journal. 2017 Jan 25; 4 (2):671-6.

11. Sharma P. V. Suśruta Saṃhita (with an English translation and dalhana commentary): Varanasi: Chaukhamba Orientali; 2010; volume 2 (chikitsa sthana): p 328.6/2 (Haridas Āyurvēda series).

12. Sharma P.V. Susruta Samhita (with an English translation and dalhana commentary): Varanasi: Chaukhamba Orientali; 2004; volume 1 (sutra sthana); p 113.11/3 (Haridas Āyurvēda series)

13. Sharma P.V. Susruta Samhita (with an English translation and dalhana commentary): Varanasi: Chaukhamba Orientali; 2004; volume 1 (sutra sthana); p 120.11/20 (Haridas Āyurvēda series)

14. Vasant C. Patil, N.M. Rajeswari, editors. Susruta samhita (with an English translation and dalhaṇa commentary): Varanasi: chaukhamba publications; 2018; volume 2 (Cikitsasthana): p337.6/4 (Mohandas Indological series)

15. Thomson WH. The nature of haemorrhoids. Journal of British Surgery. 1975 Jul;62 (7):542-52. 
16. Priyavrat Sharma. Caraka samhita (with English translation): Varanasi: Chaukambha Orientalia;2007; volume 2 (cikitsastana): p225.14/9 (Jaikrishna das Ayurveda series).

17. Vasant C. Patil, N.M. Rajeswari, editors. Susruta samhita (with an English translation and dalhana commentary): Varanasi: chaukhamba publications; 2018; volume 2 (Nidanasthana):p19.2/4 (Mohandas Indological series).

18. Yamamoto, Masateru et al. "Hemorrhoidectomy for elderly patients aged 75 years or more, before and after studies." Annals of medicine and surgery (2012) vol. 55 88-92. 16 May. 2020, doi: 10.1016/j.amsu.2020.04.045

19. Kibret AA, Oumer M, Moges AM (2021) Prevalence and associated factors of haemorrhoids among adult patients visiting the surgical outpatient department in the University of Gondar Comprehensive Specialized Hospital, Northwest Ethiopia. PLOS ONE 16 (4): e0249736. https://doi.org/10.1371/journal.pone.0249 736

20. Choudhary, Dr Praveen. (2018). Evaluation of constipation and physiology of defecation. 10.21276/ijprhs.2018.05.02.

21. Poinsot R, Vieux F, Dubois C, Perignon M, Méjean C, Darmon N. Nutritional quality of vegetarian and nonvegetarian dishes at school are nutrient profiling systems sufficiently informative. Nutrients. 2020 Aug;12 (8):2256.

22. Negri E, Pagano R, Decarli A, La Vecchia C. Body weight and the prevalence of chronic diseases. Journal of Epidemiology \& Community Health. 1988 Mar 1;42 (1):24-9.

23. Arakeri SJ, Marathe A, Fatima SA, Kadegaon M. A study on the efficacy of Karanja Pratisaraneeya Kșāra in the management of Arshas wsr to Internal Haemorrhoids. Journal of Ayurveda and Integrated Medical Sciences. 2018 Oct 31;3 (05):64-9

\section{Source of Support: Nil Conflict of Interest: None Declared}

How to cite this URL: Basima A.P. \& Rejani H: Effect Of Citrakadi Ksara Lēpa In The Management Of Second-Degree Internal Haemorrhoids. International Ayurvedic Medical Journal \{online\} 2021 \{cited October 2021\} Available from: http://www.iamj.in/posts/images/upload/2331_2338.pdf 